\title{
Variola Virus
}

National Cancer Institute

\section{Source}

National Cancer Institute. Variola Virus. NCI Thesaurus. Code C96527.

An orthopoxvirus that is the causative agent of smallpox. 